\title{
Networking capability, entrepreneurial marketing, competitive advantage, and marketing performance
}

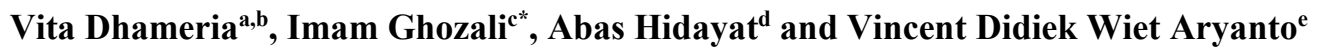

${ }^{a}$ PhD Student, Faculty of Economics and Business, Universitas Diponegoro, Semarang, Central Java, Indonesia

${ }^{b}$ Lecturer, Universitas 17 Agustus 1945 Cirebon, West Java, Indonesia

${ }^{c}$ Professor at Faculty of Economics and Business, Universitas Diponegoro, Semarang, Central Java, Indonesia

${ }^{d}$ Lecturer, Sekolah Tinggi Ilmu Kesehatan Cirebon, Indonesia

eProfessor, Faculty of Economics and Business, Universitas Dian Nuswantoro, Semarang, Central Java, Indonesia

\section{H R O N I C L E}

\section{Article history:}

Received April 8, 2021

Received in revised format May

29, 2021

Accepted July 152021

Available online

July 152021

Keywords:

SMEs

Networking Capability

Entrepreneurial Marketing

Competitive Advantage

Marketing Performance

\section{A B S T R A C T}

Business success is closely related to the marketing process. A good defined marketing strategy conducted to increase a sales business and marketing. The elements that must be developed are networking capability, entrepreneurial marketing, competitive advantage, and marketing performance. The sustainability of Indonesian businesses, especially small and medium enterprises (SMEs), is a challenge for entrepreneurs. SMEs are an important factor that affects the increase of national economic growth. This research investigated variables such as networking capability, entrepreneurial marketing, competitive advantage, marketing performance of embroidery SMEs in Tasikmalaya City West Java Indonesia. The technique sampling used in this research was purposive sampling. Samples gained were 120 SMEs. In analyzing the data, researchers employed Structural Equation Model (SEM) method from software AMOS. Entrepreneurial marketing activities are closely related to creating competitive advantage through innovation in the creation of better products, processes, and strategies to satisfy customer needs and desires. Hypothetical testing results showed that network capability and entrepreneurial marketing are important factors that significantly influence competitive advantage of SMEs. Networking capability, entrepreneurial marketing, and competitive advantage are important factors that significantly influence marketing performance of SMEs. Therefore, networking capability, entrepreneurial marketing, competitive advantage, and marketing performance must be developed for sustainable the successfulness of SMEs.

\section{Introduction}

The industrial world is getting more advanced day by day. It is marked by the presence of free industrial competition. Encouraging businesspeople to improve and maintain their business, requires business actors to continue to carry out good marketing strategies. Small and medium enterprises (SMEs) have a very important role to increase national economic growth (Lestari et al., 2020; Sanyal et al., 2020). These SMEs have not had a major impact on economic changes or the crisis of Indonesia. However, the reality is that many SMEs are experiencing problems in marketing their products. This is related to many requirements or procedures that should be faced by SMEs to get out of their trouble. Optimizing SMEs requires entrepreneurial marketing to improve performance (Sullivan Mort et al., 2012). To increase product innovation so that it can be maximally marketed requires good network capabilities (Mu \& Di Benedetto, 2012). A networking capability refers to the capability strategies that support the company to access strategic network resources and obtain their expertise and esoteric

* Corresponding author Tel.: +62231247852

E-mail address: imam.ghozali@live.undip.ac.id (I. Ghozali)

(c) 2021 Growing Science Ltd. All rights reserved.

doi: $10.5267 /$ j.uscm.2021.7.007 
knowledge for collective advantages. Network capability is needed to improve market orientation because networking capability has a significant and positive effect on business strategy (Kurniawan et al., 2020). A marketing strategy is needed that reflects sustainable competitive advantages and sustainable marketing performances (Haseeb et al., 2019). The existence of gaps in previous findings on the impact of entrepreneurial marketing and marketing performance is the starting point for this analysis. As a link between entrepreneurial marketing and marketing performance of Indonesian Batik SMEs in this study, it can be seen the effect of network capabilities on marketing performance, and product knowledge management on company performance by SMEs. Thus, the company's performance and competitive advantage are created. The competitive advantage is used as a link between entrepreneurial marketing and marketing performance. It is hoped that the company will be able to seize the market and make their product a market featured product. Entrepreneurial Marketing (EM) is mostly concerned with adapting marketing forms to suit the needs of SMEs, recognizing the potential for entrepreneurs to play a significant role in any marketing activity. Various definitions have been put forward by researchers regarding EM, but unfortunately, there is no unifying theory. Less unique definitions make research efforts remain fragmented and parallel. In addition to different definitions, the dimensions of EM also have several opinions (Morrish, 2011). Based on these problems, there is a business phenomenon in SMEs. To maintain the sustainability of SMEs towards better growth, an empirical research model is needed. This research is a case study of networking capability, entrepreneurial marketing, competitive advantage, and marketing performance on SMEs in Tasikmalaya city West Java Indonesia.

\section{Literature Review}

\subsection{Networking Capability}

A company's ability to communicate with other individuals or organizations is referred to as network capability. Networking capabilities mean all the activities, the processes, the systems and the habits in primary utilization of business process performance. (Mitrega et al., 2012). Today's market environment is extremely competitive. Therefore, networking capability is very important for the company's survival. With the network, it makes it easier for companies to get information, the resources needed by the company, market share, and the latest technology used (Miller et al., 2010). Information and social networks owned by the company are considered very important for success and sustainability (Acquaah, 2011). Not all companies have a network. However, there are formal and informal networks. Extensive companies are more likely to enter into long-term cooperation contracts, while small companies tend to only be involved in it, as a form of mutually beneficial cooperation (Tang, 2011). In informal networks, there is only technological learning and various kinds of organizational learning (Hitt et al., 2001). Human resources may also be defined as networking capability, that concluded as the act of having contact with other individuals or organizations. Networking capability is how companies identify and exploit market opportunities so that companies are able to work together, solve problems, and facilitate the development of company products (Mitrega et al., 2012). Small businesses use industry networks to find vendors, consumers, dealers, and other resources in international markets. A network is a set of interconnected exchanges between the individuals with the organizations of resource exchange required. Networks play a critical role in the internationalization of businesses, especially SMEs (Sanyal et al., 2020).

\subsection{Entrepreneurial Marketing}

Entrepreneurship is the value of creation and extraction. With this definition, entrepreneurship is viewed as change, generally entailing risk beyond what is normally encountered in starting a business, which may include other values than an economic one. Entrepreneurship is more focused on behavioral attributes, which are defined as agents of change. Humans do not have the capabilities to improve or optimize the way to do something. But they prefer to find new methods and markets, different systems of how to do something precisely (Hultman et al., 2016). Entrepreneurial Marketing (EM) is an identification proactive and exploitation of opportunities that acquires and retains profitable of customer through innovative approaches of risk management, resource exploitation, and creation value. EM is a consumer versus innovation orientation. This change is triggered by the existence of consumers who can be identified with certainty (Morgan et al., 2009). EM is a marketing activity carried out by those who are just starting up businesses and small businesses. The focus of entrepreneurs is marketing, although not all small business owners are entrepreneurs. Entrepreneurs are people who come up with new ideas (Gaddefors \& Anderson, 2009). Entrepreneurial marketing is a business process that defines, identifies, and focuses on opportunities to acquire and sustain profitable customers through productivity improvements, inventory control, and risk management (Hallbäck \& Gabrielsson, 2013). The concept of entrepreneurial marketing is a combination of the concepts of entrepreneurship and marketing. Every marketer has the opportunity to take opportunities in the market, namely how to increase revenue and market share. However, if the opportunities are not addressed with an entrepreneurial spirit, unoptimized results. EM is the process to creating, communicating, and delivering value to customers for managing customer relationships. EM is how companies pursue opportunities and develop their business by creating customer value and good relationships through innovation, creativity, sales activities, network expansion, and flexibility (Morrish, 2011). EM is how companies are able to find and take advantage of acquiring and retaining profitable customers through innovative approaches, managing risk, utilization of resources, and productivity improvements (Franco et al., 2014). The success of a small business as an entrepreneurial venture is inextricably linked to the output of its owners. Entrepreneurs handle companies by incorporating supply control, resource power, financial governance, the ability to take risks and opportunities, and marketing. Every 
entrepreneur's success becomes a challenge when it comes to achieving business goals based on opportunity and resource ownership. This will have to do with effectiveness and performance (Sariwulan et al., 2020).

\subsection{Competitive Advantage}

Competitiveness is the idea of comparing a company's ability and performance in selling and supplying products and or services to the consumer (Bambang et al., 2021). Encouraging new business ideas and creativity is an aspect of competitive advantage (Sijabat et al., 2020). Intellectual capital, competitive advantage, and creativity are essential and strategic assets for SMEs. This component makes SMEs a successful and sustainable business (Siti et al., 2021; Srikalimah et al., 2020). A competitive advantage strategy is a company advantage in terms of resources, expertise, and innovation. When the company sustains their profits that have exceeded average, it is called they have a competitive advantage than the other. The goal of every business strategy is to sustain competitive advantage. (Anning-Dorson, 2018). By applying these three competency areas, companies can develop strategies to produce products with high competitiveness in the market. Companies that have a competitive advantage can win in market competition. To be able to have a competitive advantage requires a good ability in company management.

\subsection{Marketing Performance}

Marketing performance consists of the process, technologies, and actions used by marketing organizations to make a plan of marketing activities, evaluate marketing results through established goals, and increase impactful decisions. A good corporate strategy is always aimed at creating marketing effectiveness (such as number of sales and level of sales growth). Market sensing capability is a unique capability where a company performs sensing opportunities by scanning, searching, and developing new products. This market sensing has the essence of realizing the company's potential which aims to deal with rapid environmental changes in developing new products to increase the competitive advantage of a company (Zhang et al., 2015). Market knowledge aims to find out about the various associated aspects with the business that is offering to the market. It includes a detailed study about the primary and secondary activities that a company can include in its core activities so that value can be delivered to the market. Moreover, Market knowledge is also to know about the potential consumers' behavior which is directly and indirectly connected to the products and services that one can offer. Market sense is the research technique of understanding consumers affect and the emotion that encourages consumers behavior and decision. By understanding social contexts, underlying principles, values, and other external market factors influencing their behavior can enable more powerful marketing strategies (Fahy et al., 2006). The concept of market sensing refers to the company's ability to learn about the market environment as well as to utilize knowledge capable of integrating marketing actions. Marketing performance is a means of determining how well a company is performing, which includes sales turnover, number of buyers, earnings, and increase in income (Nath et al., 2010). In the global era of SMEs marketing practices, entrepreneurs must let go of traditional concepts and replace them with new innovative thoughts and actions (Sadiku-Dushi et al., 2019).

\section{Research Method}

\subsection{Primary and Secondary Data}

Primary data of this study obtained through interviews based on a list of questions to several respondents selected for research. The data source of this research was obtained directly from filling out the questionnaire by the respondents. In this study, primary data was taken from 1,356 SMEs. All embroidered SMEs in Tasikmalaya City West Java, Indonesia were the population of this research. Secondary data of this study obtained from agencies related to embroidery SMEs, including data from BPS, the office of industry and trade, and the department of cooperatives and embroidery SMEs in Tasikmalaya City West Java Indonesia.

\subsection{Population and Sample}

A population is the pool of individuals from which a statistical sample is drawn for a study. Thus, any selection of individuals grouped together by a common feature can be said to be a population. Samples can be drawn from the population. The sample has just a statistically significant portion of a population, and it is not all over a population. The sample in this study is based on two considerations. First, the population is dynamic (the number of SMEs can increase or decrease). Second, using the maximum likelihood (ML) estimation model, this estimate requires many respondents (large sample size), that is, at least 100 to 200 respondents. There are 12 indicators in this study, the number of samples is as follows.

Sample $=$ Number of indicators $\times 10=12 \times 10=120$

The following are the criteria used to choose respondents. 1). Entrepreneurs/owners/managers have at least 3 years of work experience because they are considered to have experience in their field. 2). Entrepreneurs who have permanent workers. This means that the company is relatively stable and has been able to produce continuously. 3 ). The company carries out the production process, not just distribution. 4). National scale marketing coverage. 


\subsection{Operational Variables and Indicators}

Research variables are quantifiable abstract concepts. The latent variable of this research is an abstract concept that it cannot directly calculate (often called constructs or unobserved variables) (Kim et al., 2018). The variables in this study include exogenous and endogenous variables. Exogenous or independent variables are variables that affect the dependent variable, both of positive and negative results. Endogenous or dependent variables are variables that are influenced by independent variables and are the focus of research attention. The position of the independent and dependent variables in this study is determined by a structural model formed. This research is quantitative. For the collection of research data, research instruments were used. In that case, the research instrument was used to measure the variables under study. The variables, the operational definitions of the variables, and the indicators understudy can be explained in this table below:

\section{Table 1}

Variable Operational Definition

\begin{tabular}{|c|c|c|c|}
\hline Latent Variable & & & Indicator Variable \\
\hline $\begin{array}{l}\text { Networking } \\
\text { capability }\end{array}$ & $\begin{array}{l}\text { The act of making contact with other people or the } \\
\text { organization can also be classified as human resources. How } \\
\text { companies identify and exploit market opportunities so that } \\
\text { SMEs are able to work together, solve problems, facilitate } \\
\text { the development of SMEs products. }\end{array}$ & $\begin{array}{l}\mathrm{X} 1 \\
\mathrm{X} 2 \\
\mathrm{X} 3\end{array}$ & $\begin{array}{l}\text { Size of marketing network } \\
\text { Size of the cooperation network } \\
\text { Size of the networks between business groups }\end{array}$ \\
\hline $\begin{array}{l}\text { Entrepreneurial } \\
\text { Marketing: }\end{array}$ & $\begin{array}{l}\text { SMEs are able to define, identify and take advantage of } \\
\text { opportunities. Acquire and retain profitable customers } \\
\text { through an innovative approach. }\end{array}$ & $\begin{array}{l}\mathrm{X} 4 \\
\mathrm{X} 5 \\
\mathrm{X} 6\end{array}$ & $\begin{array}{l}\text { Proactive } \\
\text { Focus on opportunities } \\
\text { Taking risks }\end{array}$ \\
\hline $\begin{array}{l}\text { Competitive } \\
\text { advantage }\end{array}$ & $\begin{array}{l}\text { SMEs develop products or services that are superior to } \\
\text { competitors based on target markets. }\end{array}$ & $\begin{array}{l}\mathrm{X} 7 \\
\mathrm{X} 8 \\
\mathrm{X} 9\end{array}$ & $\begin{array}{l}\text { Product uniqueness } \\
\text { Product quality } \\
\text { Competitive price }\end{array}$ \\
\hline $\begin{array}{l}\text { Marketing } \\
\text { performance }\end{array}$ & $\begin{array}{l}\text { Efforts to measure of performance level which includes the } \\
\text { number of customers, sales developments and profits. }\end{array}$ & $\begin{array}{l}\mathrm{X} 10 \\
\mathrm{X} 11 \\
\mathrm{X} 12\end{array}$ & $\begin{array}{l}\text { Growth in the count of customers } \\
\text { Sales growth } \\
\text { Sales turnover growth }\end{array}$ \\
\hline
\end{tabular}

\subsection{Hypotheses}

This research used of hypotheses:

$\mathbf{H}_{1}$ : Networking capability has a significant influence on competitive advantage of SMEs in Tasikmalaya city West Java Indonesia.

$\mathbf{H}_{2}$ : Entrepreneurial marketing has a significant influence on competitive advantage of SMEs in Tasikmalaya city West Java Indonesia.

H3: Networking capability has a significant influence on marketing performance of SMEs in Tasikmalaya city West Java Indonesia.

H4: Entrepreneurial marketing has a significant influence on marketing performance of SMEs in Tasikmalaya city West Java Indonesia.

H5: Competitive advantage has a significant influence on marketing performance of SMEs in Tasikmalaya city West Java Indonesia.

\section{Results and Discussion}

\subsection{Hypotheses Test}

Fig. 1 shows the complete model testing based on the statistical package AMOS.

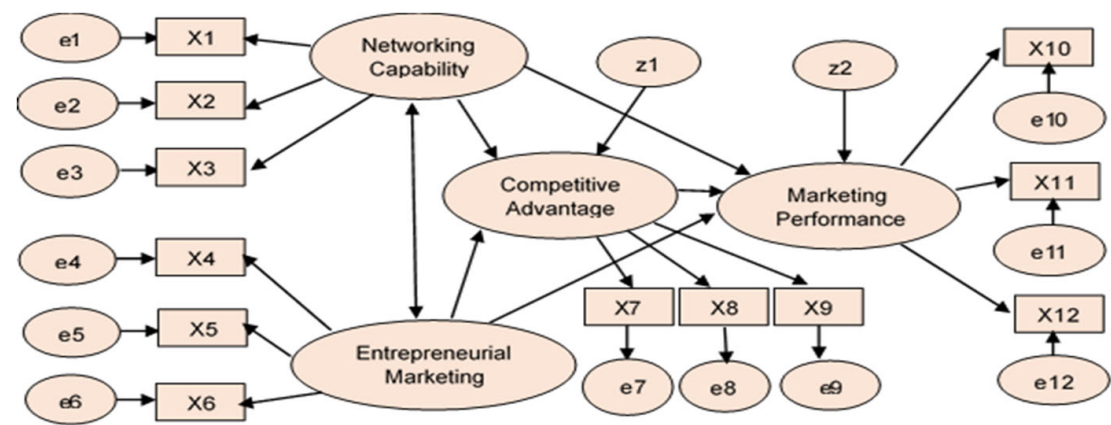

Fig. 1. Complete Model Testing 
Table 2 shows the hypotheses test results based on the output of the statistical program AMOS.

Table 2

Hypotheses Test Results

\begin{tabular}{|c|c|c|c|c|c|c|c|c|}
\hline Hypothesized variables & & & Estimate & SE & CR & $\mathbf{P}$ & $\mathbf{H}$ & Support \\
\hline Competitive Advantage & $\leftarrow$ & Networking Capability & 0.364 & 0.103 & 3.551 & $* * *$ & $\mathrm{H}_{1}$ & Yes \\
\hline Competitive Advantage & $\leftarrow$ & Entrepreneurial Marketing & 0.512 & 0.136 & 3.773 & $* * *$ & $\mathrm{H}_{2}$ & Yes \\
\hline Marketing Performance & $\leftarrow$ & Networking Capability & 0.232 & 0.119 & 2.476 & 0.021 & $\mathrm{H}_{3}$ & Yes \\
\hline Marketing Performance & $\leftarrow$ & Entrepreneurial Marketing & 0.293 & 0.116 & 2.257 & 0.012 & $\mathrm{H}_{4}$ & Yes \\
\hline Marketing Performance & $\leftarrow$ & Competitive Advantage & 0.513 & 0.101 & 5.059 & $* * *$ & $\mathrm{H}_{5}$ & Yes \\
\hline
\end{tabular}

Based on data from SMEs Tasikmalaya West Java Indonesia in table 2, it can be concluded that networking capability has a significant and positive impact on competitive advantage of SMEs, $\mathrm{H}_{1}$ is accepted, indicated by CR value 3.551 with probability $0.000<0.05$. Entrepreneurial marketing has a significant and positive impact on competitive advantage of SMEs, $\mathrm{H}_{2}$ is accepted, indicated by CR value 3.773 with probability $0.000<0.05$. Networking capability has a significant and positive impact on marketing performance of SMEs, $\mathrm{H}_{3}$ is accepted, indicated by $\mathrm{CR}$ value 2.476 with probability $0.021<0.05$. Entrepreneurial marketing has a significant and positive impact on marketing performance of SMEs, $\mathrm{H}_{4}$ is accepted, indicated by $C R$ value 2.257 with probability $0.012<0.05$. Competitive advantage has a significant and positive impact on marketing performance of SMEs, $\mathrm{H}_{5}$ is accepted, indicated by $\mathrm{CR}$ value 5.059 with probability $0.000<0.05$.

\subsection{Relationship Between Networking Capability and Competitive Advantage}

The greater a company's focus on its customers, it can develop a competitive advantage through innovation and marketing strategy (Zhou et al., 2009). One important aspect of marketing performance is the competitive advantage, which shows how a business can compete and have an advantage over its competitors. The value that a company develops for its customers gives it a competitive advantage. Network capability finds network partners and manages network relationships to establish the competitive advantage of SMEs. Being able to manage network relationships shows the proficiency of SMEs relations in network control that is effective, efficient, and contributes to the sustainability of SMEs performance. According to previous research, network capability is an important factor that significantly affects company performance (Mitrega et al., 2012).

\subsection{Relationship Between Entrepreneurial Marketing and Competitive Advantage}

Entrepreneurial marketing can support companies in identifying, evaluating, capturing opportunities and to reach and maintain competitive advantage. Entrepreneurial marketing is how companies pursue opportunities and develop their business by creating customer value through good relationships, innovation, creativity, sales activities, network expansion, and flexibility (Morrish, 2011). Multinational and international companies encourage co-creation marketing and innovation, while small companies apply low-cost marketing strategies to strengthen the competitive advantage with limited resources. Entrepreneurial marketing processes should be used creatively to have superior value to the company's consumers and owners (Miles \& Darroch, 2006). Entrepreneurship creates uncertainty because the situation is unpredictable, yields and value allocations are assessed individually and created in a complex ecosystem. Uncertainty can reduce an effectiveness of traditional marketing which has its roots in risk-based analysis used in predicting future market conditions. Entrepreneurial marketing must be developed to maintain the sustainability of SMEs competitive advantage and be ready to compete in the market.

\subsection{Relationship Between Networking Capability and Marketing Performance}

Building new relationships is important to develop orientation to be innovative to build higher performance (Asemokha et al., 2019). Network capability is not only looking for and managing the external network of the company but also talks about network relationships within the company itself. The components of networking capabilities consist of finding the partner and managing relationships to develop SMEs. The components of network capability consist of the company's ability to organize partners who collaborate with them, the ability of the company's interpersonal relations to influence partners, have information or knowledge about company partners and competitors and possess communication skills to build new relationships. This component can be called coordination, relationship skills, partner knowledge, and communication. This component is needed to improve the marketing performance of SMEs. SMEs will find it easier to identify the market and its distribution channels through the marketing network that SMEs have established (Sadiku-Dushi et al., 2019). That way, SMEs can easily take advantage of their network in product innovation to develop product marketing strategies. Network capabilities must be developed for sustainable marketing performance of SMEs.

\subsection{Relationship Between Entrepreneurial Marketing and Marketing Performance}

Marketing problems that occur include the high level of competition, the absence of own brands and stores, weak price bargaining, and limited information and market insights. On the other hand, the scale of the home industry business, whose production is limited to orders and individual businesses, contributes to weak marketing. Weak product innovation, limited 
capital, the inability of business actors, and low entrepreneurial spirit also affect product marketing coverage. To solve these marketing problems, appropriate marketing methods and strategies are needed. One approach that is currently emerging in the application of product marketing by SMEs is entrepreneurial marketing. The concept of entrepreneurial marketing is a concept that initially appeared in small-scale business actors or business actors who were just starting their business. Entrepreneurial marketing is a conceptual approach that is more appropriate in terms of limited resources and problems that exist in SMEs. Entrepreneurial marketing is an alternative to marketing management approaches (Hendijani Fard \& Seyyed Amiri, 2018). Marketing performance is a variable that can be used to measure the marketing achievement of a business, including the relationship with entrepreneurial marketing. Marketing performance is a concept for measuring the market performance of a product. Marketing performance is the important element of company performance (Riswanto et al., 2020). The influence of entrepreneurial marketing results in superior marketing performance. According to previous research, entrepreneurial marketing is an important factor that has a positive performance effect (Eggers et al., 2020).

\subsection{Relationship Between Competitive Advantage and Marketing Performance}

To improve marketing performance, a considerable factor can support the improvement of a company's marketing performance, one of which is through competitive advantage. The potential of SMEs to produce unique goods and their efficiency in developing technological innovations are two main determinants of competitive advantage. SMEs should have collaboration with others partners and rivals to establish a powerful network to gain and maintain a competitive advantage. Therefore, the collaboration between organizations can help SMEs to be very innovative, as they expose companies to new technologies and new business strategies. According to previous research, the competitive advantage strategy makes SMEs a successful and sustainable business (Siti et al., 2021; Srikalimah et al., 2020). The concept of marketing performance is widely discussed by many scientific researchers who point out the various measures used to show a company's performance in the marketing or divisional field. Marketing performance is essential to business success because of market strategies for customers, markets, and financial organizations, market performance such as sales growth, market share, and market development in marketing performance studies. Market performance can help SMEs adapt to evolving market conditions, compete more effectively and increase competitive advantage (Zhang et al., 2015). The plan implemented by the company always strives to get good marketing and financial performance. Increased product sales will also automatically increase the volume of products sold as indicated by the increased sales value and are expected to meet or exceed the targeted profit. On that basis, the marketing performance component in this study is sales growth that meets or exceeds the set target, increased sales volume, and sales values that meet or exceed targets. Therefore, competitive advantage must be developed for sustainable marketing performance of SMEs.

\section{Conclusion}

Entrepreneurial marketing activities and network capability are closely related to creating competitive advantage and marketing performance through innovation in the creation of better products, processes, and strategies to satisfying customers requirement, in the globalization era and market dynamic, SMEs looking for a competitive advantage and survival with distinct resources. Marketers who have entrepreneurial skills will rely on their connections and ask customers to provide feedback on the products they have; this is is a form of activity from market intelligence. Hypothetical testing results showed that network capability and entrepreneurial marketing are important factors that significantly influence competitive advantage of SMEs. Networking capability, entrepreneurial marketing, and competitive advantage are important factors that significantly influence marketing performance of SMEs. Therefore, networking capability, entrepreneurial marketing, competitive advantage, and marketing performance must be developed for sustainable the successfulness of SMEs.

\section{References}

Acquaah, M. (2011). Utilization and value of social networking relationships in family and nonfamily firms in an African transition economy. European Management Journal, 29(5), 347-361. https://doi.org/10.1016/j.emj.2011.03.002

Anning-Dorson, T. (2018). Innovation and competitive advantage creation. International Marketing Review, 35(4), 580-600. https://doi.org/10.1108/IMR-11-2015-0262

Asemokha, A., Musona, J., Torkkeli, L., \& Saarenketo, S. (2019). Business model innovation and entrepreneurial orientation relationships in SMEs: Implications for international performance. Journal of International Entrepreneurship, 17(3), 425453. https://doi.org/10.1007/s10843-019-00254-3

Bambang, J., Udin, U., Rini, R., Titi, L., \& Fil, A. K. (2021). Strategies for MSMEs to Achieve Sustainable Competitive Advantage: The SWOT Analysis Method. The Journal of Asian Finance, Economics, and Business, 8(3), 505-515. https://doi.org/10.13106/JAFEB.2021.VOL8.NO3.0505

Eggers, F., Niemand, T., Kraus, S., \& Breier, M. (2020). Developing a scale for entrepreneurial marketing: Revealing its inner frame and prediction of performance. Journal of Business Research, 113, 72-82. https://doi.org/10.1016/j.jbusres.2018.11.051

Fahy, J., Hooley, G., Greenley, G., \& Cadogan, J. (2006). What is a marketing resource? A response to Gibbert, Golfetto and Zerbini. Journal of Business Research, 59(1), 152-154. https://doi.org/10.1016/j.jbusres.2005.03.002 
Franco, M., de Fátima Santos, M., Ramalho, I., \& Nunes, C. (2014). An exploratory study of entrepreneurial marketing in SMEs. Journal of Small Business and Enterprise Development, 21(2), 265-283. https://doi.org/10.1108/JSBED-10-20120112

Gaddefors, J., \& Anderson, A. R. (2009). Market creation: the epitome of entrepreneurial marketing practices. Journal of Research in Marketing and Entrepreneurship, 10(1), 19-39. https://doi.org/10.1108/01443571010996217

Hallbäck, J., \& Gabrielsson, P. (2013). Entrepreneurial marketing strategies during the growth of international new ventures originating in small and open economies. International Business Review, 22(6), 1008-1020. https://doi.org/10.1016/j.ibusrev.2013.02.006

Haseeb, M., Hussain, H. I., Kot, S., Androniceanu, A., \& Jermsittiparsert, K. (2019). Role of Social and Technological Challenges in Achieving a Sustainable Competitive Advantage and Sustainable Business Performance. Sustainability, 11(14), 3811. https://doi.org/10.3390/su11143811

Hendijani Fard, M., \& Seyyed Amiri, N. (2018). The effect of entrepreneurial marketing on halal food SMEs performance. Journal of Islamic Marketing, 9(3), 598-620. https://doi.org/10.1108/JIMA-12-2016-0097

Hitt, M. A., Ireland, R. D., Camp, S. M., \& Sexton, D. L. (2001). Strategic entrepreneurship: entrepreneurial strategies for wealth creation. Strategic Management Journal, 22(6-7), 479-491. https://doi.org/10.1002/smj.196

Hultman, M., Yeboah-Banin, A. A., \& Formaniuk, L. (2016). Demand- and supply-side perspectives of city branding: A qualitative investigation. Journal of Business Research, 69(11), 5153-5157. https://doi.org/10.1016/j.jbusres.2016.04.096

Kim, B., Lee, K. H., Xue, L., \& Niu, X. (2018). A review of dynamic network models with latent variables. Statistics Surveys, 12, 154-171. https://doi.org/10.1214/18-SS121

Kurniawan, R., Budiastuti, D., Hamsal, M., \& Kosasih, W. (2020). Networking capability and firm performance: The mediating role of market orientation and business process agility. Journal of Business \& Industrial Marketing, https://doi.org/10.1108/JBIM-01-2020-0023

Lestari, S. D., Leon, F. M., Widyastuti, S., Brabo, N. A., \& Putra, A. H. P. K. (2020). Antecedents and Consequences of Innovation and Business Strategy on Performance and Competitive Advantage of SMEs. The Journal of Asian Finance, Economics, and Business, 7(6), 365-378. https://doi.org/10.13106/jafeb.2020.vol7.no6.365

Miles, M. P., \& Darroch, J. (2006). Large firms, entrepreneurial marketing processes, and the cycle of competitive advantage. European Journal of Marketing, 40(5/6), 485-501. https://doi.org/10.1108/03090560610657804

Miller, N. J., Besser, T. L., \& Sattler Weber, S. (2010). Networking as the marketing strategy: A case study of small community businesses. Qualitative Market Research: An International Journal, 13(3), $253-270$. https://doi.org/10.1108/13522751011053626

Mitrega, M., Forkmann, S., Ramos, C., \& Henneberg, S. C. (2012). Networking capability in business relationships: Concept and scale development. Industrial Marketing Management, 41(5), 739-751. https://doi.org/10.1016/j.indmarman.2012.06.002

Morgan, N. A., Slotegraaf, R. J., \& Vorhies, D. W. (2009). Linking marketing capabilities with profit growth. International Journal of Research in Marketing, 26(4), 284-293. https://doi.org/10.1016/j.ijresmar.2009.06.005

Morrish, S. C. (2011). Entrepreneurial marketing: a strategy for the twenty-first century? Journal of Research in Marketing and Entrepreneurship, 13(2), 110-119. https://doi.org/10.1108/14715201111176390

Mu, J., \& Di Benedetto, A. (2012). Networking Capability and New Product Development. IEEE Transactions on Engineering Management, 59(1), 4-19. https://doi.org/10.1109/TEM.2011.2146256

Nath, P., Nachiappan, S., \& Ramanathan, R. (2010). The impact of marketing capability, operations capability and diversification strategy on performance: A resource-based view. Industrial Marketing Management, 39(2), $317-329$. https://doi.org/10.1016/j.indmarman.2008.09.001

Riswanto, A., Rasto, R., Hendrayati, H., Saparudin, M., Abidin, A. Z., \& Eka, A. P. B. (2020). The role of innovativenessbased market orientation on marketing performance of small and medium-sized enterprises in a developing country. Management Science Letters, 1947-1952. https://doi.org/10.5267/j.msl.2020.2.019

Sadiku-Dushi, N., Dana, L.-P., \& Ramadani, V. (2019). Entrepreneurial marketing dimensions and SMEs performance. Journal of Business Research, 100, 86-99. https://doi.org/10.1016/j.jbusres.2019.03.025

Sanyal, S., Hisam, M. W., \& Baawain, A. M. S. (2020). Entrepreneurial Orientation, Network Competency, and Human Capital: The Internationalization of SMEs in Oman. The Journal of Asian Finance, Economics, and Business, 7(8), 473483. https://doi.org/10.13106/jafeb.2020.vol7.no8.473

Sariwulan, T., Suparno, S., Disman, D., Ahman, E., \& Suwatno, S. (2020). Entrepreneurial Performance: The Role of Literacy and Skills. The Journal of Asian Finance, Economics, and Business, 7(11), 269-280. https://doi.org/10.13106/jafeb.2020.vol7.no11.269

Sijabat, E. A. S., Nimran, U., Utami, H. N., \& Prasetya, A. (2020). Ambidextrous Innovation in Mediating Entrepreneurial Creativity on Firm Performance and Competitive Advantage. The Journal of Asian Finance, Economics, and Business, 7(11), 737-746. https://doi.org/10.13106/jafeb.2020.vol7.no11.737

Siti, R., Widhar, P. R., \& Frans, S. (2021). The Effect of Financial and Taxation Literation on Competitive Advantages and Business Performance: A Case Study in Indonesia. The Journal of Asian Finance, Economics, and Business, 8(2), 963971. https://doi.org/10.13106/JAFEB.2021.VOL8.NO2.0963

Srikalimah, S., Wardana, L. W., Ambarwati, D., Sholihin, U., Shobirin, R. A., Fajariah, N., \& Wibowo, A. (2020). Do Creativity and Intellectual Capital Matter for SMEs Sustainability? The Role of Competitive Advantage. The Journal of Asian Finance, Economics, and Business, 7(12), 397-408. https://doi.org/10.13106/jafeb.2020.vol7.no12.397 
Sullivan Mort, G., Weerawardena, J., \& Liesch, P. (2012). Advancing entrepreneurial marketing. European Journal of Marketing, 46(3/4), 542-561. https://doi.org/10.1108/03090561211202602

Tang, Y. K. (2011). The Influence of networking on the internationalization of SMEs: Evidence from internationalized Chinese firms. International Small Business Journal: Researching Entrepreneurship, 29(4), 374-398. https://doi.org/10.1177/0266242610369748

Zhang, H., Wu, F., \& Cui, A. S. (2015). Balancing market exploration and market exploitation in product innovation: A contingency perspective. International Journal of Research in Marketing, 32(3), 297-308. https://doi.org/10.1016/j.ijresmar.2015.03.004

Zhou, K. Z., Brown, J. R., \& Dev, C. S. (2009). Market orientation, competitive advantage, and performance: A demandbased perspective. Journal of Business Research, 62(11), 1063-1070. https://doi.org/10.1016/j.jbusres.2008.10.001

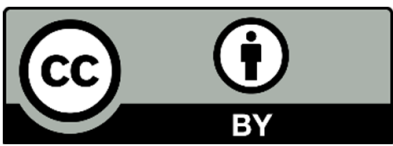

(C) 2021 by the authors; licensee Growing Science, Canada. This is an open access article distributed under the terms and conditions of the Creative Commons Attribution (CCBY) license (http://creativecommons.org/licenses/by/4.0/). 